\title{
Gene with protein product
}

INSERM

\section{Source}

INSERM. (1999). Orphanet: an online rare disease and orphan drug data base. gene with protein product. ORPHA:410298

DNA sequence translated into protein. 